\title{
ALTERATIONS IN TANYCYTES AND RELATED CELL POPULATIONS OF ARCUATE NUCLEUS IN STREPTOZOTOCIN-INDUCED ALZHEIMER DISEASE MODEL
}

Voronkov DN $\bowtie$, Stavrovskaya AV, Gushchina AS, Olshanskiy AS

Research Center of Neurology, Moscow, Russia

\begin{abstract}
It is assumed that dysfunction of tanycytes could be one of the components of pathogenesis of both Alzheimer disease and type 2 diabetes mellitus. The study was aimed to assess alterations in the tanycyte morphology in the Alzheimer disease model. The $3 \mathrm{mg} / \mathrm{kg}$ streptozotocin dose was injected in the lateral ventricles of Wistar rats in order to model the Alzheimer disease. Alterations in hypothalamic tanycytes were assessed 2 weeks, 4 weeks, 3 months and 6 months after administration of the toxin. Immunohistochemistry was used to identify the protein markers of tanycytes (vimentin, nestin), astrocytes (GFAP, glutamine synthetase) and neurons (HuC/D), as well as to assess cell proliferation (with the use of Ki67 protein) and mitochondrial alterations (mitochondrial complex IV, PGC1a). Administration of streptozotocin lead to $\beta$-amyloid accumulation in hypothalamus and ventricular enlargement $(p<0.001)$. Streptozotocin damaged both $\alpha 1 / \alpha 2$ tanycytes and $\beta 1$ tanycytes. The intensity of vimentin staining in $\alpha 1 / \alpha 2$ tanycytes decreased by week $4(p=0.003)$, and in $\beta 1$ tanycytes it decreased in three months $(p<0.001)$. The same trend was observed for nestin. The number of Ki67+ nuclei decreased $(p<0.05)$, and the expression of proteins associated with mitochondria changed. The density of hypothalamic tanycytes decreased by week 4 after administration of the toxin. Moreover, astrocyte activation was revealed. However, no prominent damage to both astrocytes and neurons was observed within four weeks after administration of streptozotocin. The revealed high tanycyte vulnerability to streptozotocin is in line with the hypothesis of the role of damage to hypothalamic structures in both local and systemic metabolic disorders occurring in the Alzheimer disease models.
\end{abstract}

Keywords: hypothalamus, tanycytes, streptozocine, Alzheimer disease

Author contribution: Voronkov DN — immunohistochemical study, morphometric study, data analysis and interpretation, manuscript writing; Stavrovskaya AV — study planning, stereotactic surgery, data analysis and interpretation, manuscript writing and editing; Gushchina AS, Olshanskiy AS — stereotactic surgery, specimens preparation for morphological study.

Compliance with ethical standards: the study was approved by the local Ethics Committee (protocol № 2-5/19 dated February 20, 2019). The animals were manipulated in accordance with the requirements of the European Convention for the Protection of Vertebral Animals Used for Experimental and Other Scientific Purposes (CETS № 170) and the Council of the European Communities Directive 2010/63/EU, order of the Ministry of Health of the Russian Federation № 119H "On Approval of Rules of Good Laboratory Practice" dated April 1, and GOST 33216-2014 "Rules for Working with Laboratory Rodents and Rabbits".

$\triangle$ Correspondence should be addressed: Dmitry N. Voronkov per. Obukha, 5, Moscow, 105064, Russia; voronkov@neurology.ru

Received: 07.10.2021 Accepted: 21.10.2021 Published online: 29.10.2021

DOI: 10.24075/brsmu.2021.050

\section{ИЗМЕНЕНИЯ ТАНИЦИТОВ И АССОЦИИРОВАННЫХ С НИМИ КЛЕТОЧНЫХ ПОПУЛЯЦИЙ АРКУАТНОГО ЯДРА В СТРЕПТОЗОЦИНОВОЙ МОДЕЛИ БОЛЕЗНИ АЛЬЦГЕЙМЕРА}

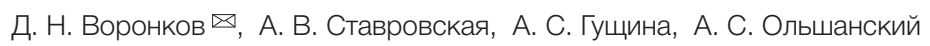

Научный центр неврологии, Москва, Россия

Предполагается, что дисфункция таницитов может быть одним из звеньев патогенеза как болезни Альцгеймера, так и диабета 2-го типа. Целью работы было охарактеризовать морфологические изменения таницитов при моделировании болезни Альцгеймера. Крысам линии Вистар вводили стрептозоцин в дозе 3 мг/Кг в латеральные желудочки мозга для моделирования болезни Альцгеймера. Оценивали изменения таницитов гипоталамуса через 2, 4 недели, 3 и 6 месяцев после введения токсина. Иммуногистохимическим методом выявляли маркерные белки таницитов (виментин, нестин), астроглии (GFAР, глутаминсинтетазы) и нейронов (HuC/D), а также оценивали пролиферацию клеток (по белку Кі67) и митохондриальные изменения (митохондриальный комплекс IV, PGC1а). Введение стрептозоцина привело к накоплению $\beta$-амилоидного пептида в гипоталамусе и увеличению размеров желудочков ( $>$ < 0,001). Стрептозоцин повреждал как $\alpha 1 / \alpha 2$, так и $\beta 1$-танициты. Интенсивность окрашивания на виментин $\alpha 1 / \alpha 2$ таницитов снижалась к 4-й неделе ( $p=0,003)$, а $\beta 1$-таницитов - через три месяца $(p<0,001)$. Ту же направленность изменений наблюдали и для нестина. Снижалось число Кі67+ ядер ( $p<0,05)$ и менялась экспрессия белков, связанных с митохондриями. К 4-й неделе после введения токсина плотность таницитов гипоталамуса снижалась. Кроме того, выявили активацию астроглии, однако выраженного повреждения как астроцитов, так и нейронов до четырех недель после введения стрептозоцина не наблюдали. Выявленная повышенная уязвимость таницитов к действию стрептозоцина согласуется с предположением о роли повреждения структур гипоталамуса в развитии как локальных, так и системных метаболических нарушений при моделировании болезни Альцгеймера.

Ключевые слова: гипоталамус, танициты, стрептозоцин, болезнь Альцгеймера

Вклад авторов: Д. Н. Воронков - иммуногистохимическое исследование, морфометрический анализ, анализ и интерпретация данных, написание рукописи; А. В. Ставровская - планирование исследования, стереотаксические операции, анализ и интерпретация данных, написание и редактирование рукописи; А. С. Гущина, А. С. Ольшанский - стереотаксические операции, подготовка материала для морфологического исследования.

Соблюдение этических стандартов: исследование одобрено локальным этическим комитетом (решение № 2-5/19 от 20 февраля 2019 г.). Манипуляции с животными проводили в соответствии с требованиями European Convention for the Protection of Vertebral Animals Used for Experimental and Other Scientific Purposes (CETS № 170) и директивой Совета европейских сообществ 2010/63/ЕС, Приказом МЗ РФ № 119 О от 1 апреля 2016 г. «Об утверждении Правил лабораторной практики», а также «Правилами работы с лабораторными грызунами и кроликами» (ГОСТ 33216-2014).

$\bowtie$ Для корреспонденции: Дмитрий Николаевич Воронков пер. Обуха, д. 5, г. Москва, 105064, Россия; voronkov@neurology.ru

Статья получена: 07.10.2021 Статья принята к печати: 21.10.2021 Опубликована онлайн: 29.10.2021

DOI: $10.24075 /$ vrgmu.2021.050 
Streptozotocin (STZ), the glucosamine-nitrosourea derivative, is an alkylating agent, which causes DNA damage resulting in reduced proliferative activity and cell death. By virtue of chemical similarity with glucose, STZ has a high affinity for glucose transporter (GLUT2). It is selectively captured by pancreatic islet $\beta$-cells, which is used for pancreatic cancer therapy and, in case of systemic administration, to model diabetes mellitus in experimental animals [1]. The study, involving the use of pancreatic islet cells, showed that streptozocin caused DNA breaks and activation of poly(ADPribose) polymerases (PARP), which in turn resulted in decreased levels of NAD (being the substrate for PARP) and cell death [2].

Single intracerebral injection of STZ causes neurodegeneration. It is assumed that STZ reduces local glucose metabolism and brain energy metabolism [3-5]. Intracerebroventricular injection of STZ results in progressive death of neurons in hippocampus and neocortex, white matter damage, and cholinergic system dysfunction, causing cognitive impairment in animals [3]. STZ-induced neurochemical changes are as follows: $\beta$-amyloid accumulation, tau hyperphosphorylation, and dysfunction of insulin receptors [6-8]. These effects of intracerebral STZ injection reproduce the features of sporadic Alzheimer disease (AD) and are in line with the "type 3 diabetes" hypothesis, which links neurodegeneration in $A D$ and local insulin resistance [9-11]. However, the precise mechanisms of STZ effects on the brain have not yet been well explored, and the hypothesis of STZ-induced direct irreversible insulin receptor desensitization is criticized by some researchers [5].

It is assumed that dysregulation of hypothalamic systems, involved in maintaining energy homeostasis, is one of the causes of AD. Neuroimaging studies have revealed changes in hypothalamic nuclei of patients with AD. According to some sources, insulin resistance and diabetes increase the risk of $A D$ [12]. However, pathologic changes in hypothalamic cell populations in the streptozotocin-induced $A D$ model have not been thoroughly explored. In particular, alterations in tanycytes of the wall of the third ventricle are of interest. Tanycytes are chemosensitive glial ependymal cells. There are several tanycyte subtypes, $\alpha 1, \alpha 2, \beta 1, \beta 2$ [13], varying in neurochemical profiles, localization in the wall of the third ventricle, and connections with hypothalamic nuclei. Tanycytes are involved in homeostatic regulation, and serve as sensors of glucose, fatty acids and other nutrients, as well as of the hormones leptin, ghrelin and insulin, involved in regulation of metabolic processes [14, 15]. The effects of targeted tanycyte injury on obesity have been described, the role of tanycytes in the control of eating behavior and association of those with orexigenic neurons of the arcuate nucleus have been demonstrated [16, 17]. Tanycyte involvement in systemic regulation of energy metabolism suggests that dysfunction of tanycytes could be one of the components of pathogenesis of both $A D$ and type 2 diabetes mellitus [15, 18]. There is no detailed description of the tanycyte response to intracerebroventricular injection of STZ. Specification of changes in hypothalamic structures in this popular $A D$ model would help us to move towards understanding the contribution of damage to hypothalamic cell populations to the pathogenetic processes in $A D$ and type 2 diabetes mellitus.

The study was aimed to assess the dynamic changes in the of hypothalamic tanycytes in the streptozotocin-induced Alzheimer disease model.

\section{METHODS}

\section{Animals}

The study involved 20 Wistar rats (males, 320-350 g, age 3 months by the beginning of the experiment) kept in the vivarium with constant access to food and water. The animals $(n=16)$ received intracerebroventricular (ICV) injections of STZ (Abcam; UK), and the control group $(n=4)$ received $0.9 \% \mathrm{NaCl}$ solution. After administration of the toxin, the animals, which received STZ, were randomly divided into four groups (four animals per group) and withdrawn from the experiment by decapitation using the guillotine (OpenScience; Russia) 2 weeks, 4 weeks, 3 months and 6 months after injection.

\section{Stereotactic surgery}

STZ was dissolved in $0.9 \% \mathrm{NaCl}$ in a dose of $3 \mathrm{mg} / \mathrm{kg}, 5 \mu \mathrm{L}$ of the solution were injected into each lateral ventricle using the stereotaxic manipulator (Stoelting; USA). The following coordinates were used for injection: $A P=-0.8 ; L=1.5 ; V=3.5$ (in accordance with Paxinos G, Watson C, "The Rat Brain in Stereotaxic Coordinates"). The combination of tiletamine/ zolazepam in a dose of $3 \mathrm{mg} / 100 \mathrm{~g}$, and intramuscular injection of the $3 \mathrm{mg} / \mathrm{kg}$ xylazine dose were used for anesthesia; the animals were premedicated with $0.04 \mathrm{mg} / \mathrm{kg}$ dose atropine administered by subcutaneous injection 10-15 min before xylazine hydrochloride administration.

\section{Immunohistochemical analysis}

For immunohistochemical study, brain specimens were fixed for $24 \mathrm{~h}$ in 4\% formalin, and impregnated with 30\% sucrose. Then the freezed frontal sections of the hypothalamus, $10 \mu \mathrm{m}$ thick, were prepared. Antigen unmasking was performed by heating the sections with citrate buffer (antigen retrieval buffer, $\mathrm{pH}=6.0$; Sigma; Germany) in the steamer for $20 \mathrm{~min}$. The study involved the use of mouse monoclonal antibodies (Abcam; UK) against tanycyte markers, nestin (Nes) and vimentin (Vim), and rabbit polyclonal antibodies (Sigma; Germany) against astroglial proteins, glial fibrillary acidic protein (GFAP) and glutamine synthetase (GS). Neurons were identified using mouse antibodies (Invitrogen; USA) against the RNA-binding protein HuC/D. Mitochondrial alterations were assessed using the rabbit antibodies (Invitrogen; USA) against PGC1 $\alpha$ (transcriptional coactivator, regulator of mitochondrial biogenesis) and MT-CO1 (cytochrome C oxidase subunit I, mitochondrial respiratory chain complex IV). Cell proliferation was evaluated using the rabbit anti-Ki67 antibody (Dako; Denmark), and $\beta$-amyloid deposits were identified using the rabbit anti- $\beta$-amyloid $1-42$ antibody (Sigma; Germany). The sections were incubated with primary antibodies for $24 \mathrm{~h}$ at room temperature; antibodies were diluted in accordance with the manufacturer's guidelines. Binding was visualized with the use of appropriate pairs of anti-mouse or anti-rabbit lgG secondary antibodies, conjugated with Alexa 488 or Alexa 555 fluorochromes (Invitrogen; USA). The slides were mounted with FluoroShield mounting medium (Abcam; UK), containing diamidino phenylindole (DAPI) for cell nuclei labeling.

\section{Morphometric study and statistical data processing}

The slides were examined using the Nikon Eclipse NiU fluorescence microscope (Nikon; Japan) with installed Nikon DS-Qi camera (Nikon; Japan) and NIS Elements software 
(Nikon; Japan). The measurements were performed on the 12bit images acquired using the same settings of the microscope illumination system with the 20x or 40x lens magnification. Areas of interest (lumen of the ventricle, cell nucleus or soma) were manually selected on the images using the graphic tablet (Wacom; Japan). Cell density and immunofluorescent stain intensity in the areas of interest were assessed in at least 25 fields of view in a series of 6-8 frontal slices acquired at various levels of hypothalamus (the results were presented as $\%$ of maximum brightness level -4096 shades of gray). A total of 150-300 cells per animal were selected in the images in order to assess the intensity of MT-CO1 and PGC1 $\alpha$ immunofluorescent staining. The data acquired for one animal were averaged. The data acquired for the group were presented as median and interquartile range (Me [LQ; HQ]). Statistical analysis was carried out using the Statistica 12.0 (StatSoft; USA) and GraphPad Prism (GraphPad Software; USA) software. The differences between groups were evaluated with the nonparametric Kruskal Wallis test and subsequent Dunn's test for paired intergroup comparisons. The differences were considered significant when $p<0.05$.

\section{RESULTS}

Intracerebroventricular injection of STZ resulted in the increasing damage to the wall of the third ventricle and hypothalamic structures. Macroanatomical study revealed the dilated third ventricle (Fig. 1A, D): in the second week after STZ administration the area of the third ventricle on the slice was significantly $(\rho<0.001)$ larger compared to controls (more than twice larger), and continued to further increase. By month 6 after administration, the area of the third ventricle on the slice increased by more than 20 times, and necrosis was revealed in the adjacent hypothalamic nuclei. Simulation of pathomorphological findings, characteristic of Alzheimer disease, upon STZ administration was confirmed by accumilation of $\beta$-amyloid peptide 1-42 in hypothalamic structures (Fig. 1B).

When detecting vimentin, damage to glioependymal elements of the wall of the third ventricle was observed (Fig. 1A). By week 4 after STZ administration, staining intensity in the zone of $\alpha 1$ and $\alpha 2$ tanycyte (forming connections with dorsomedial and ventromedial hypothalamic nuclei respectively) localization significantly decreased $(p=0.003$ ) compared to controls. The decrease in vimentin staining intensity in the zone of $\beta 1$ tanycyte (projections to the arcuate nucleus) localization wass less prominent, and significant changes $(p<0.001)$ were detected only three months after STZ administration. Ependymocytes of the dorsal region of the wall of the third ventricle remained intact until week 4 after administration of STZ. Distinct Vim+ tanycytes of the hypothalamic median eminence persisted after three months, while there were found no Vim+ ependymal cells in other regions of the wall of the third ventricle by month 6. Our study was focused mostly on assessing the changes in the wall of the third ventricle 2 and 4 weeks after STZ administration due to rapidly increasing damage to tanycytes.

Identification of both nestin and vimentin made it possible to demonstrate changes in the morphology of tanycytes. Visually, during week 2 after STZ administration, there were thickened Vim+ processes and deformation of the ventricular wall ependymal layer in the zone of $\beta 1$ tanycyte localization and the tranzition zone ( $\beta 1 / \alpha 2$ tanycytes) (Fig. 2A). Similar changes were found when detecting nestin (Fig. 2A). The nestin staining intensity decreased by week 4 after STZ administration
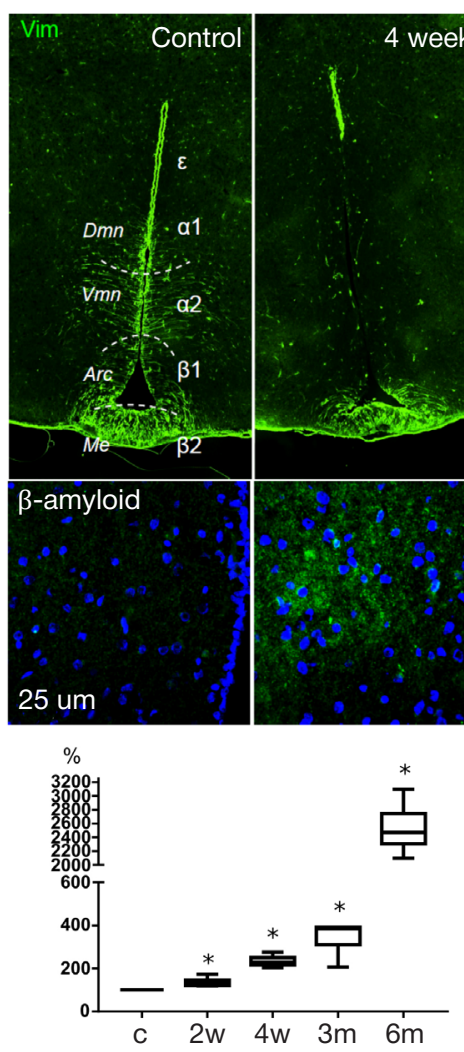
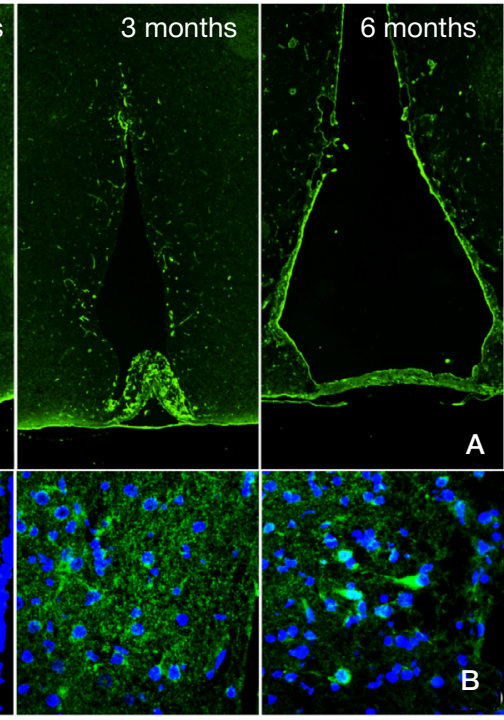

Brightness (\%)

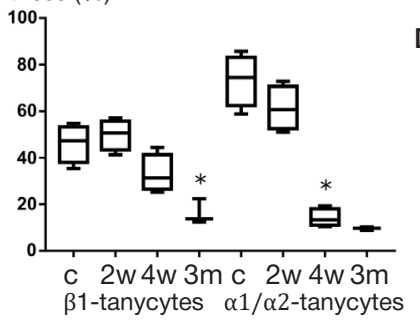

Fig. 1. Streptozotocin-induced changes in the third ventricle and adjacent structures. A. Identification of vimentin (Vim). B. Identification of $\beta$-amyloid in hypothalamic arcuate nucleus. C. Changes in the area of the third ventricle, \% of the value of control (c). D. Changes in vimentin staining intensity (brightness, \% of maximum levels) in the zone of $\beta 1$ tanycyte and $\alpha 1 / \alpha 2$ tanycyte localization. c - control; $2 \mathrm{w}, 4 \mathrm{w}, 3 \mathrm{~m}, 6 \mathrm{~m}$ - groups 2 and 4 weeks, 3 and 6 months after administration of streptozotocin; * - $p<0.05$; populations of tanycytes $(\alpha 1, \alpha 2, \beta 1, \beta 2)$ and ependymocytes $(\varepsilon)$ are denoted by Greek letters; Dmn — dorsomedial hypothalamic nucleus; Vmn — ventromedial hypothalamic nucleus; Arc — hypothalamic arcuate nucleus; Me — hypothalamic median eminence 

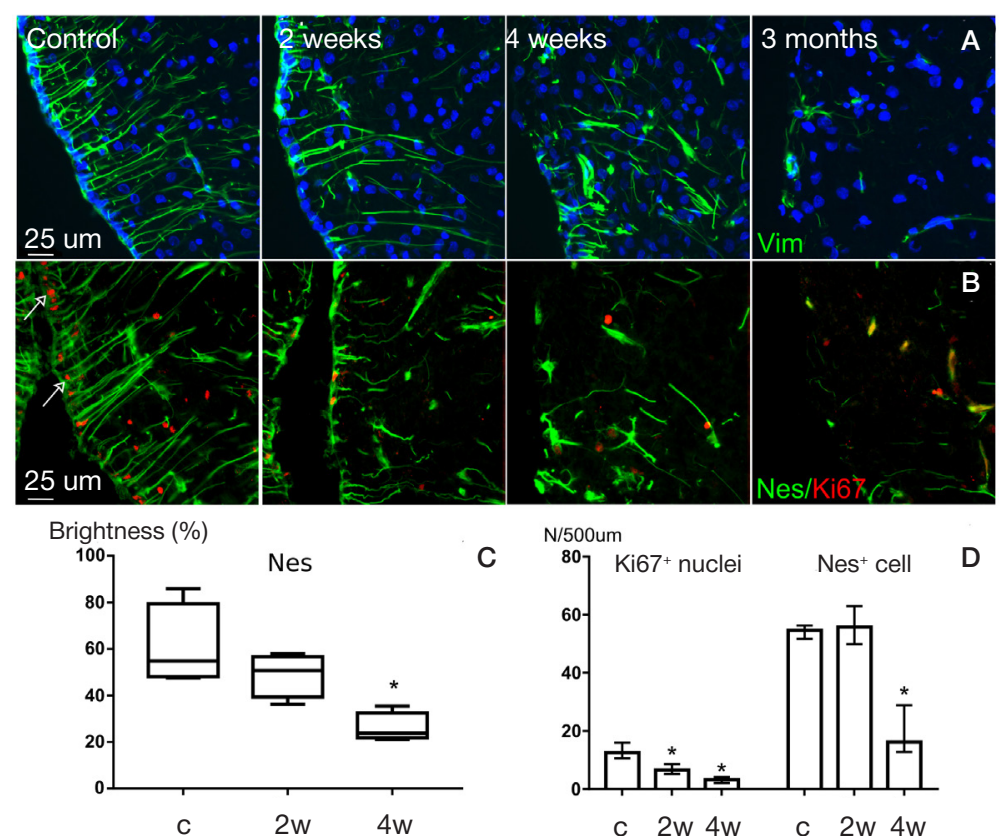

Fig. 2. Streptozotocin-induced changes in the morphology of tanycytes. A. Identification of vimentin (shown in green), DAPI staining of nuclei (blue). B. Identification of nestin (green) and Ki67 (red; arrows point to Ki67-positive nuclei). C. Changes in nestin staining intensity (brightness, \% of maximum levels). D. Changes in the number of $\mathrm{Nes}^{+}$and $\mathrm{Ki}^{+} 7^{+}$glial ependymal cells (number per unit of ventricular wall length). For notation see Fig. 1

compared to controls $(p=0.024)$, along with the $\mathrm{Nes}^{+} \beta 1$ tanycyte density $(p<0.001)$ (Fig. 2C, D). However, the number of Ki-67-positive nuclei in tanycytes significantly decreased $(p=0.049$; Fig. 2D) by week 2 , which confirmed the effects of STZ on the proliferative activity of cells.

The damage to tanycytes was preceded by altered expression of proteins, associated with mitochondrial functions. Reduced intensity of tanycyte cytoplasm staining with antiMTCO1 (mitochondrial respiratory chain complex IV) antibody compared to controls $(p=0.013)$ was observed starting from week 2 after STZ administration, earlier than the reduction of tanycyte density and the decrease in nestin expression (Fig. 3A, B). Furthermore, MT-CO1 staining in cell bodies of the adjacent arcuate nucleus persisted, and counting neurons of the arcuate nucleus during weeks 2 and 4 after STZ administration revealed no significant decrease in the neuronal density compared to controls. Detection of transcriptional coactivator PGC1a (involved in regulation of a number of mitichondrial functions)
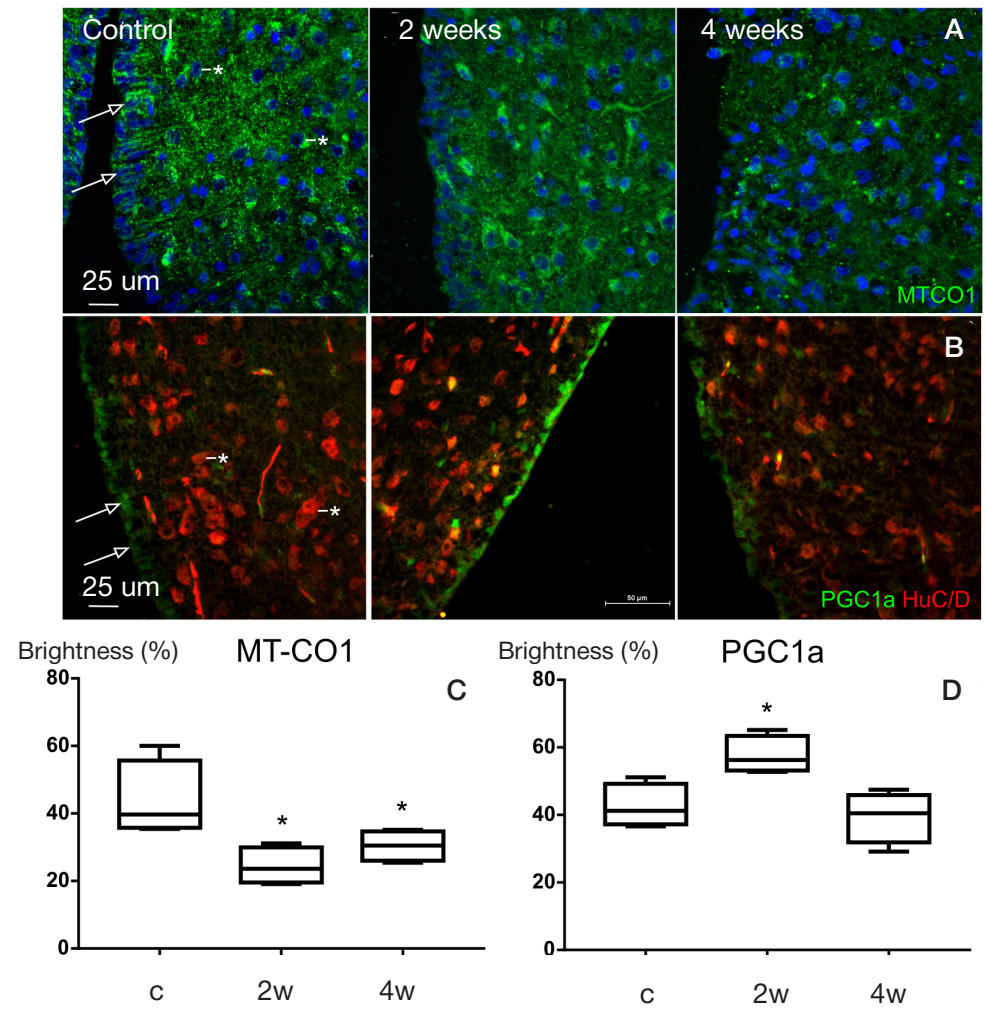

Fig. 3. Identification of tanycyte proteins associated with mitochondrial functions. A. Identification of MT-CO1 (mitochondrial respiratory chain complex IV); DAPI staining of nuclei (shown in blue). B. Identification of PGC1a (green); neurons (red) were identified using the anti-HuC/D antibodies. C. Changes in tanycyte cell body MT-CO1 staining intensity (brightness, \% of maximum levels). D. Changes in tanycyte cell nuclei PGC1a staining intensity (brightness, \% of maximum levels). Arrows point to tanycytes, neurons are marked with asterisks. For notation see Fig. 1 

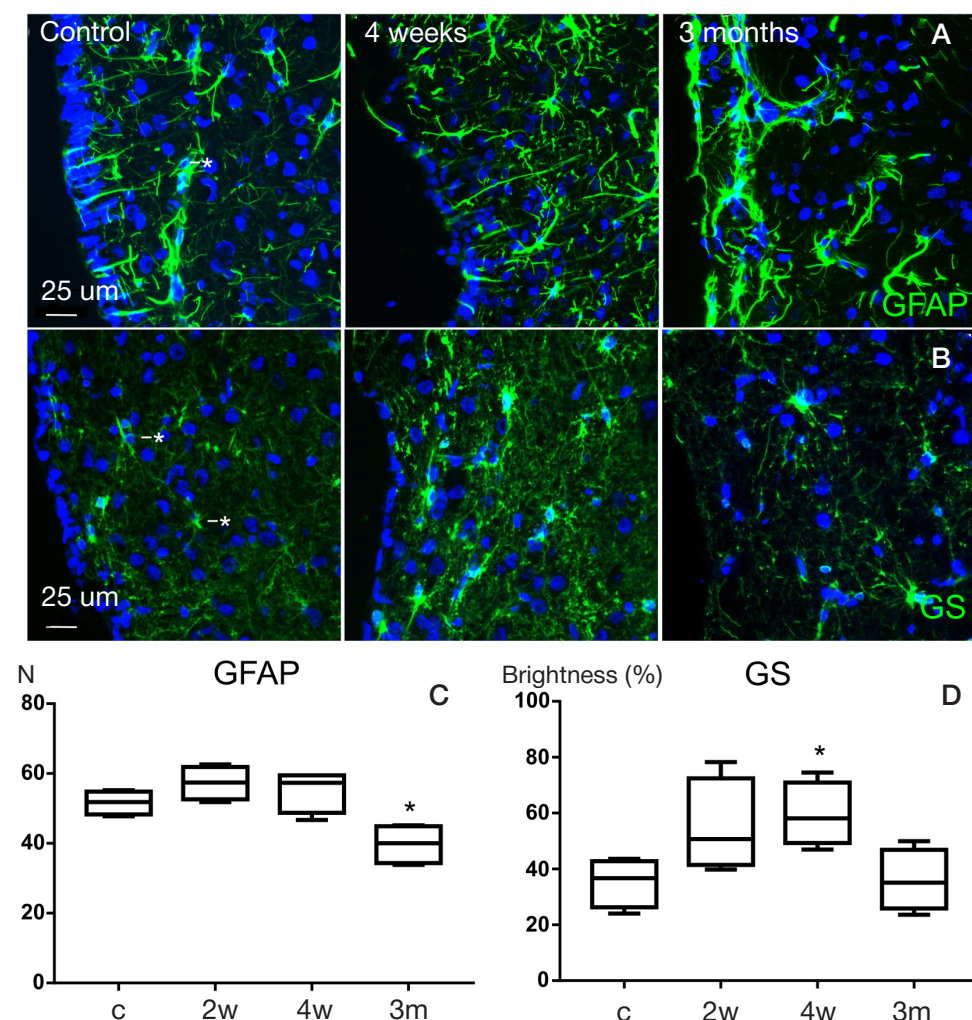

Brightness (\%)

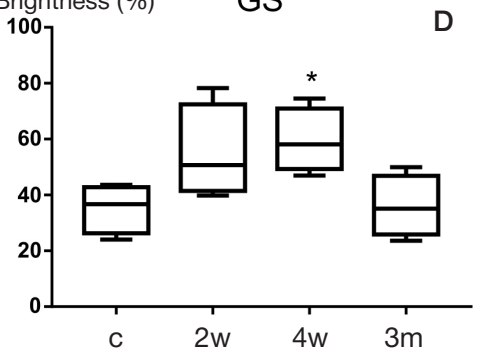

Fig. 4. Streptozotocin-induced changes in astroglia in the zone of hypothalamic arcuate nucleus (in the vicinity of the wall of the third ventricle). A. Identification of GFAP (shown in green); DAPI staining of nuclei (blue). B. Identification of glutamine synthetase (GS, green); DAPI staining of nuclei (b/ue). C. Changes in the number of GFAP-positive cells in the field of view. D. Changes in glutamine synthetase staining intensity (brightness, \% of maximum levels). Astrocytes are marked with asterisks. For notation see Fig. 1

revealed the significantly $(p=0.048)$ increased intensity of tanycyte nuclei staining by week 2 (Fig. 3B, C), while during week 4 after STZ administration, PGC1a staining intensity dropped to control values.

Immunohistochemical identification of GFAP and glutamine synthetase (GS) was used to assess the astroglial changes. In intact animals, GFAP was detected in the substantial proportion of ependymal cells, however, GS expression levels in tanycytes appeared to be negligible compared to astroglia. Changes in the morphology of the GFAP-positive astrocytes in the arquate nucleus had been already indicative of the STZ-induced reactive gliosis by week 2: thickening, deformation of processes and increased staining for glial cell markers were observed (Fig. 4A, B). The GS staining intensity increased by week $4(p=0.03)$, which was probably due to the increased area of astrocytes on the slice (Fig. 4B, D). However, the number (density) of astrocytes did not increase early after STZ administration and significantly decreased compared to controls by month 3 $(p=0.019$; Fig. $4 \mathrm{C})$. In general, changes in astroglia were indicative of the increasing neuroinflammatory response in hypothalamic structures adjacent to the third ventricle. Although STZ caused damage to astrocytes, these cells appeared to be more resistant to the toxin compared to tanycytes.

To summarize the findings, it can be noted that STZ administration resulted in $\beta$-amyloid accumulation in hypothalamic structures, including neurons of arcuate nucleus, and in ventricular enlargement, which was probably due to the damage to glial ependymal elements. Tanycytes of various types were susceptible to STZ, however, both $\alpha 1 / \alpha 2$ tanycytes and $\beta 1$ tanycytes were damaged early after STZ administration, as manifested in reduced proliferative activity and altered expression of proteins, associated with mitochondria. These alterations occurred before the detection of the prominent tanycyte morphology impairment. The $\beta 1$ tanycyte density in the third ventricle decreased by week 4 after STZ administration. Moreover, STZ caused reactive changes in astrocytes and damage to astroglia, however, there were no changes in the density of both astrocytes and neurons of arcuate nucleus within four weeks after administration of the toxin, which was indicative of higher tanycyte vulnerability to STZ compared to other hypothalamic cell populations.

\section{DISCUSSION}

The majority of papers on studying morphological and neurochemical changes in streptozotocin-induced models are focused on hippocampal research due to the role of hippocampus in cognitive impairment, associated with $A D$. These data are in line with alterations, revealed during our study. Thus, experiments, involving intraventricular or intracisternal STZ administration, demonstrate $\beta$-amyloid accumulation in hippocampus three months after administration of the toxin, altered expression of synaptic proteins, as well as neuronal cell death and reduced hippocampal volume [3, 19]. The effects of STZ on the hippocampal astrocytes have been identified: the reduced number and altered structure of the astrocyte processes have been demonstrated [20]. Reduced hippocampal expression of insulin receptors upon administration of STZ has been found [21]. Since astrocytes are believed to be the target cells for insulin, and the knockout of astrocytic insulin receptors leads to cognitive impairment in animals [22], it can be assumed that dysfunction in glial components plays a vital part in STZ-induced localized metabolic disorders.

No data on tanycyte alterations in humans with $A D$ have been presented in the literature. Only the age-related changes in the tanycyte processes' organization have been described [23]. However, degenerative changes, $\beta$-amyloid accumulation 


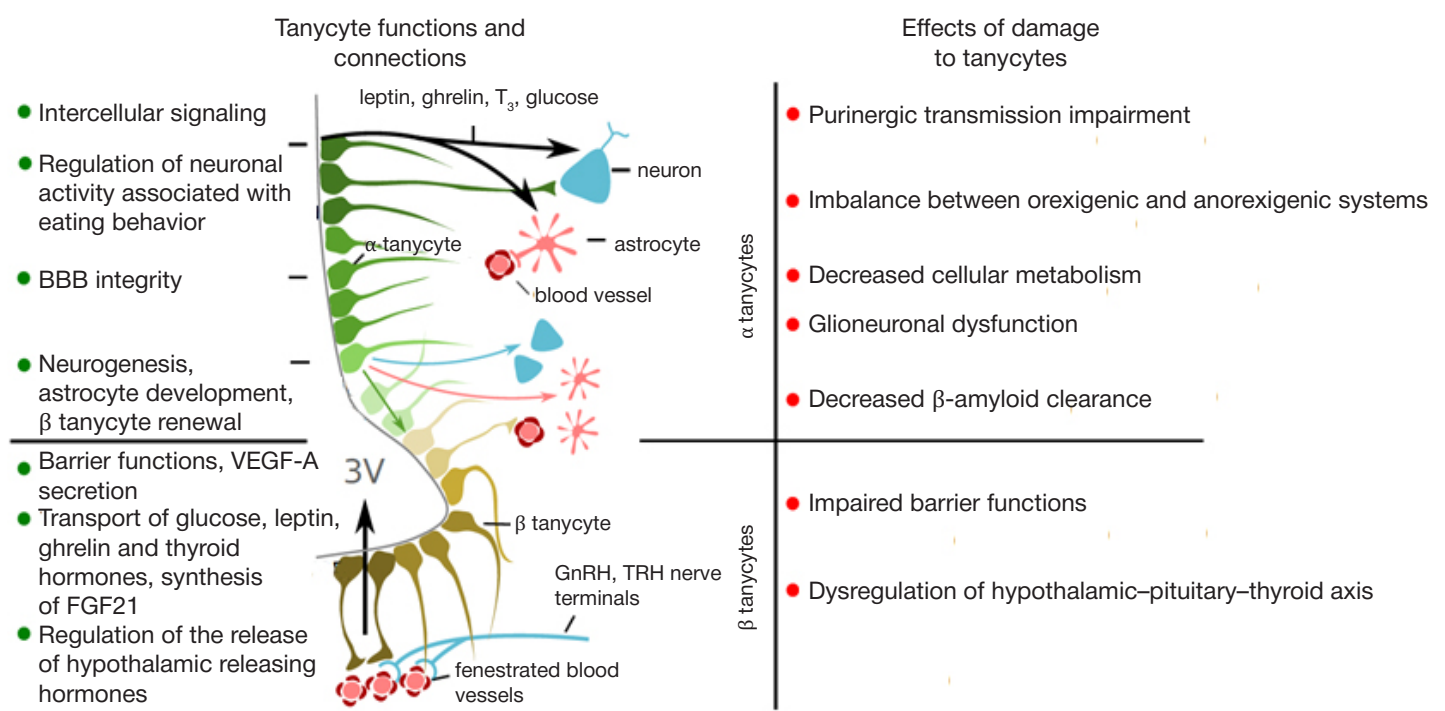

Fig. 5. Interaction between tanycytes and hypothalamic structures, and potential effects of damage to tanycytes. BBB — blood-brain barrier; VEGF-A — vascular endothelial growth factor A; FGF21 — fibroblast

and mitochondrial dysfunction in hypothalamic nuclei are found during pathological studies [24].

The mechanisms, underlying hypothalamic dysfunction in humans with $A D$, are poorly understood. Apart from neurodegeneration, many researchers assign an important role to alterations in synthesis, secretion and transport of hypothalamic hormones and factors [18, 24], involved in homeostatic regulation of hypothalamic-pituitary axis, which could be mediated by dysfunction of tanycytes. For example, tanycytes are involved in regulation of the thyroliberin release and serve as a main source of triiodothyronine in the brain. Furthermore, neuroprotective effects of both thyroliberin and triiodothyronine have been demonstrated in $\mathrm{AD}$ models $[25,26]$.

Tanycytes express the GLUT2 transporter [13, 27] and are therefore one of the target cells for STZ; the damage to tanycytes, revealed during our study, is the intended effect of the toxin administration. The cause of the more prominent damage to $\alpha$ tanycytes, observed during our study, may be associated with uneven pattern of glucose transporter expression and the frequency of various tanycyte populations renewal, as well as with tanycyte metabolic features, which should be further clarified. The differences seen in dynamic changes in nestin and vimentin levels can be explained by the fact that the content of vimentin in $\alpha$ and $\beta$ tanycytes is different, although all types of tanycytes express these proteins [18]. Moreover, there have been reports of multidirectional changes in regulation of cytoskeletal proteins in tanycytes [28].

It is important that the STZ-induced changes in tanycytes preceded other hypothalamic changes, associated with neurodegeneration and neuroinflammation. In general, considering the fact that tanycytes modulate neurons of ventromedial, dorsomedial and arcuate hypothalamic nuclei, and are involved in regulation of both local and systemic energy metabolism, as well as in regulation of eating behavior $[15,18,29]$, the damage to tanycytes is likely to result in the carbohydrate metabolism disorders, observed in this $A D$ model [30, 31]. However, hypothalamic dysfunction upon STZ administration and the previously reported hypothalamic neurodegeneration during the final stages [31] may be triggered by neuroinflammatory response, involving tanycytes and other cell populations.

The decreased intensity of tanycyte staining for MTC01 (cytochrome C oxidase subunit I) we have identified is consistent with the decreased cytochrome $\mathrm{C}$ oxidase activity in streptozotocin-induced diabetes model [32]. Studying brain cortex and hippocampus in animals, which received STZ, revealed reduced activity of pyruvate dehydrogenase, $\alpha$-ketoglutarate dehydrogenase, and cytochrome $\mathrm{C}$ oxidase in mitochondria of both neocortex and hippocampus [33]. Moreover, the reduced activity of mitochondrial complexes IIII upon intracerebroventricular injection of STZ was revealed [34]. These data emphasize mitochondrial sensitivity to STZ, previously studied in vitro [35]. The increased expression of PGC1a (regulator of mitochondrial biogenesis), observed early after STZ administration, could be considered a compensatory response to the developing disorders. The return to baseline PGC1a levels could be indicative of partial function recovery in the intact tanycytes. In turn, PGC1a dysregulation is associated with neuroinflammatory processes and could be considered one of the factors, contributing to neuronal damage in AD [36, 37]. The STZ-induced dynamic changes in mitochondrial dysfunction, observed in various structures, have yet to be assessed.

It would be interesting to juxtapose the observed STZinduced decrease in tanycyte proliferation with the previously reported effects of this toxin on the hippocampal neural stem cells [38], as well as with its high toxicity in immature neurons [39]. Since tanycytes are likely to have neurogenic potential [40], the STZ-induced impairment of proliferation and apoptosis in hypothalamic neural stem cells can exert the long-term effects, associated with impaired plasticity of hypothalamic neural networks, involved in homeostatic control.

Fig. 5 (according to $[14,15,17,18])$ summarizes some functions of $\alpha$ and $\beta$ tanycytes, which are suspected of being involved in pathological changes in the streptozotocininduced $\mathrm{AD}$ models. The potential tanycyte involvement in the pathogenesis of $A D$ suggests the possibility of developing the pharmacological methods for the tanycyte function correction. Some authors believe that the tanycyte proliferation regulation via exposure to growth factors could be provided [18].

\section{CONCLUSIONS}

The findings demonstrate increased sensitivity of hypothalamic tanycytes to STZ, reduced tanycyte proliferative activity and the associated mitochondrial alterations. Astrocyte activation and neuronal damage are preceded by alterations in tanycytes. The changes, observed in the mediobasal hypothalamus, suggest that the damage to tanycytes plays a vital part in local 
and systemic metabolic disorders occurring in the Alzheimer disease models. The possible functional consequences of damage to tanycytes are as follows: impaired barrier function and downregulated cellular metabolism in hypothalamic structures, unbalanced orexigenic and anorexigenic effects, dysregulation of the hypothalamic-pituitary-thyroid axis.

\section{References}

1. Elsner M, Guldbakke B, Tiedge M, Munday R, Lenzen S. Relative importance of transport and alkylation for pancreatic beta-cell toxicity of streptozotocin. Diabetologia. 2000; 43 (12): 1528-33.

2. Guzyk MM, Dyakun KO, Yanytska LV, Pryvrotska IB, Krynytska IY, Pishel IM, et al. Inhibitors of Poly(ADP-Ribose)Polymerase-1 as Agents Providing Correction of Brain Dysfunctions Induced by Experimental Diabetes. Neurophysiology. 2017; 49 (3): 183-93.

3. Knezovic A, Osmanovic-Barilar J, Curlin M, Hof PR, Simic G, Riederer P, et al. Staging of cognitive deficits and neuropathological and ultrastructural changes in streptozotocin-induced rat model of Alzheimer's disease. Journal of Neural Transmission. 2015; 122 (4): 577-92.

4. Osmanovic-Barilar J, Knezovic A, Grünblatt E, Riederer P, Salkovic-Petrisic, M. Nine-month follow-up of the insulin receptor signalling cascade in the brain of streptozotocin rat model of sporadic Alzheimer's disease. Journal of Neural Transmission. 2015; 122 (4): 565-76.

5. Grieb P. Intracerebroventricular Streptozotocin Injections as a Model of Alzheimer's Disease: in Search of a Relevant Mechanism. Molecular Neurobiology. 2016; 53 (3): 1741-52.

6. Grünblatt E, Salkovic-Petrisic M, Osmanovic J, Riederer P, Hoyer S. Brain insulin system dysfunction in streptozotocin intracerebroventricularly treated rats generates hyperphosphorylated tau protein. Journal of Neurochemistry. 2007; 101 (3): 757-70.

7. Rajasekar N, Dwivedi S, Nath C, Hanif K, Shukla R. Protection of streptozotocin induced insulin receptor dysfunction, neuroinflammation and amyloidogenesis in astrocytes by insulin. Neuropharmacology. 2014; 86: 337-52.

8. Ravelli KG, Rosário B dos A, Camarini R, Hernandes MS, Britto LR. Intracerebroventricular Streptozotocin as a Model of Alzheimer's Disease: Neurochemical and Behavioral Characterization in Mice. Neurotoxicity Research. 2017; 31 (3): 327-33.

9. Kandimalla R, Thirumala V, Reddy PH. Is Alzheimer's disease a Type 3 Diabetes? A critical appraisal. Biochimica et Biophysica Acta (BBA) - Molecular Basis of Disease. 2017; 1863 (5): 107889.

10. Gupta S, Yadav K, Mantri SS, Singhal NK, Ganesh S, Sandhir R. Evidence for Compromised Insulin Signaling and Neuronal Vulnerability in Experimental Model of Sporadic Alzheimer's Disease. Molecular Neurobiology. 2018; 55 (12): 8916-35.

11. Gorina YaV, Komleva YuK, Lopatina OL, Chernyh Al, Salmina AB. Jekspressija molekul - komponentov insulin-oposredovannoj signal'noj transdukcii $v$ kletkah golovnogo mozga pri jeksperimental'noj bolezni Al'cgejmera. Annaly klinicheskoj jeksperimental'noj nevrologii. 2019; 13 (4): 28-37. DOI: 10.25692/ ACEN.2019.4.5. Russian.

12. Vercruysse P, Vieau D, Blum D, Petersen A, Dupuis L. Hypothalamic Alterations in Neurodegenerative Diseases and Their Relation to Abnormal Energy Metabolism. Front Mol Neurosci. 2018; 11: 2. DOI: 10.3389/fnmol.2018.00002.

13. Rizzoti K, Lovell-Badge R. Pivotal role of median eminence tanycytes for hypothalamic function and neurogenesis. Molecular and Cellular Endocrinology. 2017; 445: 7-13.

14. Geller S, Arribat $Y$, Netzahualcoyotzi C, Lagarrigue S, Carneiro L, Zhang L, et al.Tanycytes Regulate Lipid Homeostasis by Sensing Free Fatty Acids and Signaling to Key Hypothalamic Neuronal Populations via FGF21 Secretion. Cell Metabolism. 2019; 30 (4): 833-44.

15. Bolborea $M$, Langlet $F$. What is the physiological role of hypothalamic tanycytes in metabolism? American Journal of Physiology-Regulatory, Integrative and Comparative Physiology. 2021; 320 (6): R994-R1003.

16. Yoo S, Cha D, Kim S, Jiang L, Cooke P, Adebesin M, et al. Tanycyte ablation in the arcuate nucleus and median eminence increases obesity susceptibility by increasing body fat content in male mice. Glia. 2020; 68 (10): 1987-2000.

17. Bolborea M, Pollatzek E, Benford H, Sotelo-Hitschfeld T, Dale N. Hypothalamic tanycytes generate acute hyperphagia through activation of the arcuate neuronal network. Proceedings of the National Academy of Sciences. 2020; 117 (25): 14473-81.

18. Raikwar SP, Bhagavan SM, Ramaswamy SB, Thangavel R, Dubova I, Selvakumar GP, et al. Are Tanycytes the Missing Link Between Type 2 Diabetes and Alzheimer's Disease? Molecular Neurobiology. 2019; 56 (2): 833-43.

19. Ahn Y, Seo J, Park J, Won J, Yeo HG, Kim K, et al. Synaptic loss and amyloid beta alterations in the rodent hippocampus induced by streptozotocin injection into the cisterna magna. Lab Anim Res. 2020; 36: 17

20. Zappa Villar MF, López Hanotte J, Falomir Lockhart E, Trípodi LS, Morel GR, Reggiani PC. Intracerebroventricular streptozotocin induces impaired Barnes maze spatial memory and reduces astrocyte branching in the CA1 and CA3 hippocampal regions. J Neural Transm (Vienna). 2018; 125 (12): 1787-803. DOI: 10.1007/ s00702-018-1928-7.

21. Agrawal R, Tyagi E, Shukla R, Nath C. Insulin receptor signaling in rat hippocampus: a study in STZ (ICV) induced memory deficit model. Eur Neuropsychopharmacol. 2011; 21 (3): 261-73. DOI: 10.1016/j.euroneuro.2010.11.009.

22. González-García I, Gruber T, García-Cáceres, C. Insulin action on astrocytes: From energy homeostasis to behaviour. J Neuroendocrinol. 2021; 33 (4): e12953. DOI: 10.1111/jne.12953.

23. Koopman ACM, Taziaux M, Bakker J. Age-related changes in the morphology of tanycytes in the human female infundibular nucleus/median eminence. J Neuroendocrinol. 2017; 29 (5). DOI: 10.1111/jne. 12467

24. Ishii M, ladecola C. Metabolic and Non-Cognitive Manifestations of Alzheimer's Disease: The Hypothalamus as Both Culprit and Target of Pathology. Cell Metab. 2015; 22 (5): 761-76. DOI: 10.1016/j.cmet.2015.08.016

25. Daimon CM, Chirdon P, Maudsley S, Martin B. The role of Thyrotropin Releasing Hormone in aging and neurodegenerative diseases. Am J Alzheimers Dis (Columbia). 2013; 1 (1). 10. DOI: 10.7726/ajad.2013.1003

26. Rodríguez-Rodríguez A, Lazcano I, Sánchez-Jaramillo E, Uribe RM, Jaimes-Hoy L, Joseph-Bravo P, et al. Tanycytes and the Control of Thyrotropin-Releasing Hormone Flux Into Portal Capillaries. Front Endocrinol (Lausanne). 2019; 10: 401. DOI: 10.3389/ fendo.2019.00401.

27. García M de los A, Millán C, Balmaceda-Aguilera C, Castro T, Pastor P, Montecinos $\mathrm{H}$, et al. Hypothalamic ependymal-glial cells express the glucose transporter GLUT2, a protein involved in glucose sensing. Journal of Neurochemistry. 2003; 86 (3): 709-24.

28. Lewis JE, Ebling FJ. Tanycytes As Regulators of Seasonal Cycles in Neuroendocrine Function. Front Neurol. 2017; 8: 79. DOI: 10.3389/fneur.2017.00079. PMID: 28344570; PMCID: PMC5344904.

29. Uranga RM, Millán C, Barahona MJ, Recabal A, Salgado M, Martinez $F$, et al. Adenovirus-mediated suppression of hypothalamic glucokinase affects feeding behavior. Scientific Reports. 2017; 7 (1): 3697.

30. Bloch K, Gil-Ad I, Vanichkin A, Hornfeld SH, Koroukhov N, Taler M, et al. Intracerebroventricular Streptozotocin Induces Obesity and Dementia in Lewis Rats. Journal of Alzheimer's Disease. 2017; 60 (1): $121-36$

31. Stavrovskaya AV, Voronkov DN, Shestakova EA, Gushchina AS, Olshansky AS, Yamshikova NG. Streptozocin-inducirovannaja bolezn' Al'cgejmera kak samostojatel'nyj faktor riska razvitija giperglikemii u krys linii Vistar. Problemy jendokrinologii. 2019; 65 
(5): 351-61. Russian

32. Raza H, Prabu SK, John A, Avadhani NG. Impaired Mitochondrial Respiratory Functions and Oxidative Stress in StreptozotocinInduced Diabetic Rats. International Journal of Molecular Sciences. 2011; 12 (5): 3133-47.

33. Correia SC, Santos RX, Santos MS, Casadesus G, LaManna JC, Perry G, et al. Mitochondrial Abnormalities in a StreptozotocinInduced Rat Model of Sporadic Alzheimer's Disease. Current Alzheimer Research. 2013; 10 (4). Available from: https://DOI.org /10.2174/1567205011310040006

34. Poddar J, Singh S, Kumar P, Bali S, Gupta S, Chakrabarti S Inhibition of complex I-III activity of brain mitochondria after intracerebroventricular administration of streptozotocin in rats is possibly related to loss of body weight. Heliyon. 2020; 6 (7): e04490.24

35. Genrikhs EE, Stelmashook EV, Golyshev SA, Aleksandrova OP, Isaev NK. Streptozotocin causes neurotoxic effect in cultured cerebellar granule neurons. Brain Research Bulletin. 2017; 130: 90-94. ht

\section{Литература}

1. Elsner M, Guldbakke B, Tiedge M, Munday R, Lenzen S. Relative importance of transport and alkylation for pancreatic beta-cel toxicity of streptozotocin. Diabetologia. 2000; 43 (12): 1528-33.

2. Guzyk MM, Dyakun KO, Yanytska LV, Pryvrotska IB, Krynytska IY, Pishel IM, et al. Inhibitors of Poly(ADP-Ribose)Polymerase-1 as Agents Providing Correction of Brain Dysfunctions Induced by Experimental Diabetes. Neurophysiology. 2017; 49 (3): 183-93.

3. Knezovic A, Osmanovic-Barilar J, Curlin M, Hof PR, Simic G, RiedererP, et al. Staging of cognitive deficits and neuropathological and ultrastructural changes in streptozotocin-induced rat mode of Alzheimer's disease. Journal of Neural Transmission. 2015; 122 (4): 577-92

4. Osmanovic-Barilar J, Knezovic A, Grünblatt E, Riederer P, Salkovic-Petrisic, M. Nine-month follow-up of the insulin receptor signalling cascade in the brain of streptozotocin rat model of sporadic Alzheimer's disease. Journal of Neural Transmission. 2015; 122 (4): 565-76.

5. Grieb P. Intracerebroventricular Streptozotocin Injections as a Model of Alzheimer's Disease: in Search of a Relevant Mechanism. Molecular Neurobiology. 2016; 53 (3): 1741-52.

6. Grünblatt E, Salkovic-Petrisic M, Osmanovic J, Riederer P, Hoyer S. Brain insulin system dysfunction in streptozotocin intracerebroventricularly treated rats generates hyperphosphorylated tau protein. Journal of Neurochemistry. 2007; 101 (3): 757-70.

7. Rajasekar N, Dwivedi S, Nath C, Hanif K, Shukla R. Protection of streptozotocin induced insulin receptor dysfunction, neuroinflammation and amyloidogenesis in astrocytes by insulin. Neuropharmacology. 2014; 86: 337-52.

8. Ravelli KG, Rosário B dos A, Camarini R, Hernandes MS, Britto LR Intracerebroventricular Streptozotocin as a Model of Alzheimer's Disease: Neurochemical and Behavioral Characterization in Mice. Neurotoxicity Research. 2017; 31 (3): 327-33.

9. Kandimalla R, Thirumala V, Reddy PH. Is Alzheimer's disease a Type 3 Diabetes? A critical appraisal. Biochimica et Biophysica Acta (BBA) - Molecular Basis of Disease. 2017; 1863 (5): 107889.

10. Gupta S, Yadav K, Mantri SS, Singhal NK, Ganesh S, Sandhir R. Evidence for Compromised Insulin Signaling and Neurona Vulnerability in Experimental Model of Sporadic Alzheimer's Disease. Molecular Neurobiology. 2018; 55 (12): 8916-35.

11. Горина Я. В., Комлева Ю. К., Лопатина О. Л., Черных А. И., Салмина А. Б. Экспрессия молекул - компонентов инсулинопосредованной сигнальной трансдукции в клетках головного мозга при экспериментальной болезни Альцгеймера. Анналь клинической и экспериментальной неврологии. 2019; 13 (4): 28-37. DOI: 10.25692/ACEN.2019.4.5.

12. Vercruysse P, Vieau D, Blum D, Petersen A, Dupuis L. Hypothalamic Alterations in Neurodegenerative Diseases and Their Relation to Abnormal Energy Metabolism. Front Mol Neurosci. 2018; 11: 2. DOI: 10.3389/fnmol.2018.00002.
36. Sweeney G, Song J. The association between PGC-1 $\alpha$ and Alzheimer's disease. Anatomy and Cell Biology. 2016; 49 (1): 1.

37. Rius-Pérez S, Torres-Cuevas I, Millán I, Ortega ÁL, Pérez S. PGC-1 $\alpha$, Inflammation, and Oxidative Stress: An Integrative View in Metabolism. Oxidative Medicine and Cellular Longevity. 2020; $1-20$.

38. Sun P, Ortega G, Tan Y, Hua Q, Riederer PF, Deckert J, et al. Streptozotocin Impairs Proliferation and Differentiation of Adult Hippocampal Neural Stem Cells in Vitro-Correlation With Alterations in the Expression of Proteins Associated With the Insulin System. Frontiers in Aging Neuroscience. 2018; 10. Available from: https://DOI.org/10.3389/fnagi.2018.00145.

39. Isaev NK, Genrikhs EE, Voronkov DN, Kapkaeva MR, Stelmashook EV. Streptozotocin toxicity in vitro depends on maturity of neurons. Toxicology and Applied Pharmacology. 2018; 348: 99-104.

40. Yoo S, Kim J, Lyu P, Hoang TV, Ma A, Trinh V, et al. Control of neurogenic competence in mammalian hypothalamic tanycytes. Science Advances. 2021; 7 (22): eabg3777. Available from: https://DOl.org/10.1126/sciadv.abg3777.

13. Rizzoti K, Lovell-Badge R. Pivotal role of median eminence tanycytes for hypothalamic function and neurogenesis. Molecular and Cellular Endocrinology. 2017; 445: 7-13.

14. Geller S, Arribat Y, Netzahualcoyotzi C, Lagarrigue S, Carneiro L, Zhang L, et al.Tanycytes Regulate Lipid Homeostasis by Sensing Free Fatty Acids and Signaling to Key Hypothalamic Neuronal Populations via FGF21 Secretion. Cell Metabolism. 2019; 30 (4): 833-44

15. Bolborea $M$, Langlet $F$. What is the physiological role of hypothalamic tanycytes in metabolism? American Journal of Physiology-Regulatory, Integrative and Comparative Physiology. 2021; 320 (6): R994-R1003

16. Yoo S, Cha D, Kim S, Jiang L, Cooke P, Adebesin M, et al. Tanycyte ablation in the arcuate nucleus and median eminence increases obesity susceptibility by increasing body fat content in male mice. Glia. 2020; 68 (10): 1987-2000.

17. Bolborea M, Pollatzek E, Benford H, Sotelo-Hitschfeld T, Dale N. Hypothalamic tanycytes generate acute hyperphagia through activation of the arcuate neuronal network. Proceedings of the National Academy of Sciences. 2020; 117 (25): 14473-81.

18. Raikwar SP, Bhagavan SM, Ramaswamy SB, Thangavel R, Dubova I, Selvakumar GP, et al. Are Tanycytes the Missing Link Between Type 2 Diabetes and Alzheimer's Disease? Molecular Neurobiology. 2019; 56 (2): 833-43.

19. Ahn Y, Seo J, Park J, Won J, Yeo HG, Kim K, et al. Synaptic loss and amyloid beta alterations in the rodent hippocampus induced by streptozotocin injection into the cisterna magna. Lab Anim Res. 2020; 36: 17.

20. Zappa Villar MF, López Hanotte J, Falomir Lockhart E, Trípodi LS, Morel GR, Reggiani PC. Intracerebroventricular streptozotocin induces impaired Barnes maze spatial memory and reduces astrocyte branching in the CA1 and CA3 hippocampal regions. J Neural Transm (Vienna). 2018; 125 (12): 1787-803. DOI: 10.1007/s00702-018-1928-7.

21. Agrawal $R$, Tyagi $E$, Shukla $R$, Nath $C$. Insulin receptor signaling in rat hippocampus: a study in STZ (ICV) induced memory deficit model. Eur Neuropsychopharmacol. 2011; 21 (3): 261-73. DOI: 10.1016/j.euroneuro.2010.11.009.

22. González-García I, Gruber T, García-Cáceres, C. Insulin action on astrocytes: From energy homeostasis to behaviour. $J$ Neuroendocrinol. 2021; 33 (4): e12953. DOl: 10.1111/jne.12953.

23. Koopman ACM, Taziaux M, Bakker J. Age-related changes in the morphology of tanycytes in the human female infundibular nucleus/median eminence. J Neuroendocrinol. 2017; 29 (5). DOI: 10.1111/jne.12467.

24. Ishii M, ladecola C. Metabolic and Non-Cognitive Manifestations of Alzheimer's Disease: The Hypothalamus as Both Culprit and Target of Pathology. Cell Metab. 2015; 22 (5): 761-76. DOI: 10.1016/j.cmet.2015.08.016

25. Daimon CM, Chirdon P, Maudsley S, Martin B. The role of 
Thyrotropin Releasing Hormone in aging and neurodegenerative diseases. Am J Alzheimers Dis (Columbia). 2013; 1 (1). 10. DOI: 10.7726/ajad.2013.1003

26. Rodríguez-Rodríguez A, Lazcano I, Sánchez-Jaramillo E, Uribe RM, Jaimes-Hoy L, Joseph-Bravo P, et al. Tanycytes and the Control of Thyrotropin-Releasing Hormone Flux Into Portal Capillaries. Front Endocrinol (Lausanne). 2019; 10: 401. DOI: 10.3389/ fendo.2019.00401.

27. García M de los A, Millán C, Balmaceda-Aguilera C, Castro T, Pastor P, Montecinos $\mathrm{H}$, et al. Hypothalamic ependymal-glial cells express the glucose transporter GLUT2, a protein involved in glucose sensing. Journal of Neurochemistry. 2003; 86 (3): 709-24.

28. Lewis JE, Ebling FJ. Tanycytes As Regulators of Seasonal Cycles in Neuroendocrine Function. Front Neurol. 2017; 8: 79. DOI: 10.3389/fneur.2017.00079. PMID: 28344570; PMCID: PMC5344904

29. Uranga RM, Millán C, Barahona MJ, Recabal A, Salgado M, Martinez $F$, et al. Adenovirus-mediated suppression of hypothalamic glucokinase affects feeding behavior. Scientific Reports. 2017; 7 (1): 3697.

30. Bloch K, Gil-Ad I, Vanichkin A, Hornfeld SH, Koroukhov N, Taler M, et al. Intracerebroventricular Streptozotocin Induces Obesity and Dementia in Lewis Rats. Journal of Alzheimer's Disease. 2017; 60 (1): 121-36.

31. Ставровская А. В., Воронков Д. Н., Шестакова Е. А., Гущина А. С., Ольшанский А. С., Ямщикова Н. Г. Стрептозоцининдуцированная болезнь Альцгеймера как самостоятельный фактор риска развития гипергликемии у крыс линии Вистар. Проблемы эндокринологии. 2019; 65 (5): 351-61.

32. Raza H, Prabu SK, John A, Avadhani NG. Impaired Mitochondria Respiratory Functions and Oxidative Stress in StreptozotocinInduced Diabetic Rats. International Journal of Molecular Sciences. 2011; 12 (5): 3133-47.
33. Correia SC, Santos RX, Santos MS, Casadesus G, LaManna JC, Perry G, et al. Mitochondrial Abnormalities in a StreptozotocinInduced Rat Model of Sporadic Alzheimer's Disease. Current Alzheimer Research. 2013; 10 (4). Available from: https://DOl.org /10.2174/1567205011310040006

34. Poddar J, Singh S, Kumar P, Bali S, Gupta S, Chakrabarti S. Inhibition of complex I-III activity of brain mitochondria after intracerebroventricular administration of streptozotocin in rats is possibly related to loss of body weight. Heliyon. 2020; 6 (7): e04490.24.

35. Genrikhs EE, Stelmashook EV, Golyshev SA, Aleksandrova OP, Isaev NK. Streptozotocin causes neurotoxic effect in cultured cerebellar granule neurons. Brain Research Bulletin. 2017; 130: 90-94. ht

36. Sweeney G, Song J. The association between PGC-1 $\alpha$ and Alzheimer's disease. Anatomy and Cell Biology. 2016; 49 (1): 1.

37. Rius-Pérez S, Torres-Cuevas I, Millán I, Ortega ÁL, Pérez S. PGC-1 $\alpha$, Inflammation, and Oxidative Stress: An Integrative View in Metabolism. Oxidative Medicine and Cellular Longevity. 2020; $1-20$.

38. Sun P, Ortega G, Tan Y, Hua Q, Riederer PF, Deckert J, et al. Streptozotocin Impairs Proliferation and Differentiation of Adult Hippocampal Neural Stem Cells in Vitro-Correlation With Alterations in the Expression of Proteins Associated With the Insulin System. Frontiers in Aging Neuroscience. 2018; 10. Available from: https://DOI.org/10.3389/fnagi.2018.00145.

39. Isaev NK, Genrikhs EE, Voronkov DN, Kapkaeva MR, Stelmashook EV. Streptozotocin toxicity in vitro depends on maturity of neurons. Toxicology and Applied Pharmacology. 2018; 348: 99-104.

40. Yoo S, Kim J, Lyu P, Hoang TV, Ma A, Trinh V, et al. Control of neurogenic competence in mammalian hypothalamic tanycytes. Science Advances. 2021; 7 (22): eabg3777. Available from: https://DOI.org/10.1126/sciadv.abg3777. 